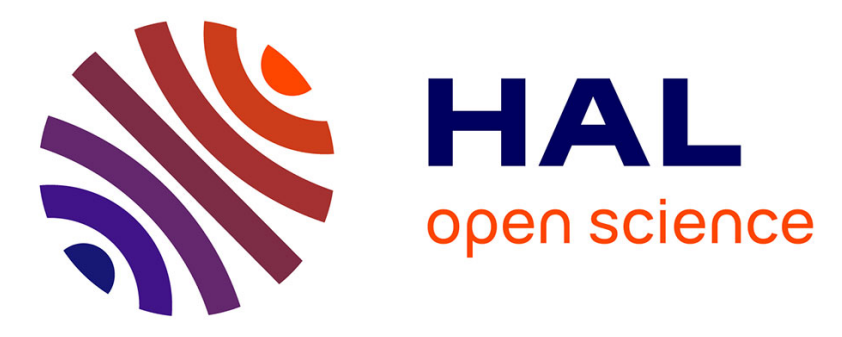

\title{
Environmental benzene exposure assessment for parent-child pairs in Rouen, France
}

Amin Kouniali, André Cicolella, Norbert Gonzalez-Flesca, Roland Dujardin, J.F. Gehanno, Frédéric Y. Bois

\section{- To cite this version:}

Amin Kouniali, André Cicolella, Norbert Gonzalez-Flesca, Roland Dujardin, J.F. Gehanno, et al.. Environmental benzene exposure assessment for parent-child pairs in Rouen, France. Science of the Total Environment, 2003, 308 (1-3), pp.73-82. 10.1016/S0048-9697(02)00631-9 . ineris-00961875

\section{HAL Id: ineris-00961875}

https://hal-ineris.archives-ouvertes.fr/ineris-00961875

Submitted on 20 Mar 2014

HAL is a multi-disciplinary open access archive for the deposit and dissemination of scientific research documents, whether they are published or not. The documents may come from teaching and research institutions in France or abroad, or from public or private research centers.
L'archive ouverte pluridisciplinaire HAL, est destinée au dépôt et à la diffusion de documents scientifiques de niveau recherche, publiés ou non, émanant des établissements d'enseignement et de recherche français ou étrangers, des laboratoires publics ou privés. 


\section{ENVIRONMENTAL BENZENE EXPOSURE ASSESSMENT FOR PARENT-CHILD PAIRS IN ROUEN, FRANCE}

Amin KOUNIALI ${ }^{\mathrm{a}}$, André CICOLELLA ${ }^{\mathrm{a}, *}$, Norbert GONZALEZ-FLESCA $^{\mathrm{a}}$,

Roland DUJARDIN ${ }^{\mathrm{a}}$, Jean-François GEHANNO ${ }^{\mathrm{b}}$, Frédéric Y. BOIS $^{\mathrm{a}}$

${ }^{a}$ INERIS, Institut National de l'Environnement Industriel et des Risques, 60550 Verneuil-en-Halatte, France.

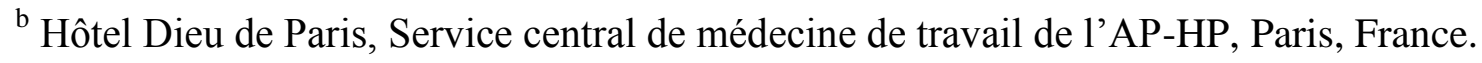

*Corresponding author. Tel.: + 333445562 02; Fax. : + 33344556899 .

E-mail : andre.cicolella@ineris.fr

Abbreviations: MA, trans,trans-muconic acid; HQ, hydroquinone; $r$, Pearson's correlation coefficient. 


\begin{abstract}
There is a lack of data on children environmental benzene exposure. In this study we compared personal benzene exposure and inhalation uptake in a group of children to those of their parents. We also compared levels of urinary benzene metabolites, trans,trans-muconic acid (MA) and hydroquinone (HQ), for those two groups, and assess the correlation between personal benzene exposure and urinary MA and HQ concentrations.
\end{abstract}

The study was performed on twenty-one, 2- to 3-year-old children and their parents recruited on a voluntary basis among non smokers from the three largest day care centers of the town of Rouen in France. Average benzene concentrations were measured over 5 consecutive days with diffusive samplers. The following simultaneous measurements were carried out: personal exposure of the parents, concentrations inside and outside the day care centers and inside the volunteer's bedrooms. Morning and evening urine samples were collected during the same period.

Benzene personal exposure levels were $14.4 \pm 7.7 \mu \mathrm{g} / \mathrm{m}^{3}$ and $11.09 \pm 6.15 \mu \mathrm{g} / \mathrm{m}^{3}$ in parents and children respectively. Benzene inhalation uptake estimates were $2.51 \pm 1.23 \mu \mathrm{g} / \mathrm{kg}$-day in the group of parents and $5.68 \pm 3.17 \mu \mathrm{g} / \mathrm{kg}$-day in the group of children.

Detectable levels of MA and HQ were found in $85 \%$ and $100 \%$ of the samples respectively. Intra-individual variation of urinary MA and HQ concentrations expressed as a coefficient of variation (CV) ranged from 63 to $232 \%$ and from 13 to $144 \%$, respectively. Mean values of MA and HQ (in mg/g creatinine) were 1.6- and 1.8-fold higher in the group of children than in the group of parents ( $p=0.008$ and $p<0.0001$ respectively).

Significant correlations between metabolites levels and benzene were not found. 
Keywords: Benzene; Exposure; Children; trans,trans-muconic acid; Hydroquinone; Urine. 


\section{Introduction}

Environmental benzene exposure is potentially an important health concern. Benzene is an ubiquitary pollutant (Wallace, 1989) and severe adverse health effects have occurred in occupationally exposed workers (US-EPA, 1997). It is clearly established and accepted that benzene exposure can cause acute non-lymphocytic leukemia and a variety of other bloodrelated disorders in humans (US-EPA, 1997).

The evaluation of risk posed by exposure to relatively low concentrations of benzene from occupational and environmental source is an active area of research. Benzene cancer risk assessments generally rely upon observations made in occupationally exposed population. The effect of exposure to benzene could potentially be different in children. However, there are insufficient data on differences in metabolism between adults and children for benzene (US-EPA, 1998). Moreover, environmental benzene exposure data in children are very limited.

Children are likely to have higher benzene uptake per unit body weight than adults because of their heightened activity, as well as different ventilation volumes per time and ventilation frequency (US-EPA, 1997). Infants and children may be more vulnerable to leukemogenesis because their hematopoietic cell populations are differentiating and undergoing maturation (US-EPA, 1998). Weaver et al. (1996) conducted a pilot study to evaluate the feasibility of using trans,trans-muconic acid (MA) as a biomarker for environmental benzene exposure in urban children. In a recent study conducted on 144 children living in Italy, Amodio-Cocchieri et al. (2001) also used MA as a biomarker for environmental exposure. Measurements of benzene biomarkers, which can provide information on individual variation in absorption and 
metabolism and, thus susceptibility to adverse health effects, appear to be useful in the case of benzene.

Our study's aim was to investigate the possibility that children are more susceptible than adults to benzene exposure. To minimize the impact of genetic and lifestyle differences, we (A) compared the personal benzene exposure and inhalation uptake in a group of children to those of their parents after performing personal, indoor and outdoor measurements. We also (B) compared levels of urinary MA and hydroquinone (HQ), another benzene metabolite, for those two groups. Moreover, we (C) examined the correlation between personal benzene exposure and urinary MA and HQ concentrations. 


\section{Materials and methods}

\subsection{Study design}

Study participants were recruited from the three largest public day care centers of the town of Rouen in France (each frequented by more than 60 children). A letter of solicitation had been sent by the director of each day care center to families meeting to certain criteria. The targeted population was non-smoking parents of "clean" children (needing no diapers), 2 to 3 years old. Father, mother or both were invited to participate with their children(s) in the study. Of the 50 families that were invited, 43 members of 20 families participated (individual written consents were collected) in the survey: twenty-one children (16 females and 5 males) and 22 non-smoking parents (17 mothers and 5 fathers). Their distribution within day care centers is given in the Table 1. Day care center B had 3 independent sections (sections 1, 2 and 3).

The measurement campaigns were conducted over the working week (Monday morning to Friday evening) (Table 1). Two urine samples were collected per day, one in the morning (between 7:00 and 10:00), the other in the evening (between 18:00 and 21:00). They were stored at $-20^{\circ} \mathrm{C}$ until analysis.

In order to evaluate benzene exposure of the subjects, indoor measurements were carried out in parents and children's bedrooms and in the day care centers. Passive samplers used for indoor monitoring were attached to ad hoc supports, $1.5 \mathrm{~m}$ above the floor level. To measure background levels around the day care centers, outdoor monitoring was conducted in the front of the centers by placing samplers inside purpose-built aluminum shelters, attached at a height of $3 \mathrm{~m}$. Each parent also carried one personal sampler within his/her breathing zone. This personal sampler was left open during the night in the bedroom according to a method previously described (Gonzalez-Flesca et al., 2000). All of the parents worked indoors in an 
office. All sampling was carried out by passive means, which allows determination of an average concentration for the whole exposure period (from Monday morning to Friday evening). 


\subsection{Chemicals analysis}

\subsubsection{Benzene air concentrations}

Benzene was sampled using Radiello Perkin Elmer (RPE) axial diffusive samplers assembled and validated at INERIS. Analyses were performed on an automatic thermal desorption apparatus (ATD400, Perkin Elmer) linked to Chrompack CP-9002 gas-chromatograph equipped with FID and a Chrompack Column (CP-Sil 5CB; $50 \mathrm{~m} \times 0.32 \mathrm{~mm}$ od; Film thickness $1.2 \mu \mathrm{m}$; Chrompack, The Netherlands). A full description and details of RPE validation is given elsewhere (Bates et al., 1997).

\subsubsection{MA concentrations in urine}

A high-performance liquid chromatography (HPLC) method adapted from that of Ducos et al. (1990) and Lee et al. (1993a) was used. Two ml of urine sample were adjusted to pH 4.5-5.7 with concentrated HCL and then applied on a Bond Elut extraction cartridge filled with 500 mg of SAX sorbent (Varian, France) (preconditioned with $3 \mathrm{ml}$ of acetonitrile and $3 \mathrm{ml}$ of distilled water) at a flow rate of $0.5 \mathrm{ml} / \mathrm{min}$ using a Rapid-Trace automatic peristaltic pump from Zymarck (France). After the addition of urine, the cartridge was washed 3 times with 3 $\mathrm{ml}$ of $1 \%$ acetic acid at $2 \mathrm{ml} / \mathrm{min}, 5 \mathrm{ml}$ of distilled water at $20 \mathrm{ml} / \mathrm{min}$, and $5 \mathrm{ml}$ of acetonitrile at $20 \mathrm{ml} / \mathrm{min}$. MA was finally eluated with $4 \mathrm{ml}$ of $10 \%$ acetic acid at $0.5 \mathrm{ml} / \mathrm{min}$. Twenty microliters of this eluate was injected in the chromatograph for analysis (Varian 9012 equipped with an UV detector 9050). The HPLC column was a SAX C18 $5 \mu \mathrm{m}(25 \mathrm{~cm} \times 4.6$ $\mathrm{mm}$ ) analytical column. Chromatography was isocratic in a mobile phase consisting of glacial acetic acid, $1 \mathrm{M}$ sodium acetate, and methanol (4.5/1.8/100 ml) q.s.f. $1000 \mathrm{ml}$ of water at $\mathrm{pH}$ 3.0 at a flow rate of $1.5 \mathrm{ml} / \mathrm{min}$. UV detection of MA was performed at a wavelength of 265 nm. All chemicals and water used were HPLC grade (Aldrich, France). MA stock, working 
standard solutions, and calibration curves were obtained according to Ducos et al. (1990). The MA detection limit, obtained from spiked urine calibration curves, was $20 \mu \mathrm{g} / \mathrm{l}$.

\subsection{3. $H Q$ concentrations in urine}

Urinary HQ was measured according to the method described by Lee et al. (1993b) with minor modifications. Briefly, a $1 \mathrm{ml}$ urine sample (previously adjusted to $\mathrm{pH} 4.5-5.3$ ) was hydrolyzed with $0.1 \mathrm{ml}$ of concentrated hydrochloric acid at $100^{\circ} \mathrm{C}$ for $120 \mathrm{~min}$. Following cooling to room temperature, the sample was extracted with $2 \mathrm{ml}$ of diethyl ether. Twenty microliters of the extract were then injected in the chromatograph (Varian 9012 equipped with a fluorometric detector 9070 and an ODS $5 \mu \mathrm{m} \mathrm{n}^{\circ} 241$ analytical column) with fluorimetric detection $\left(\lambda_{\text {ex }} 304 \mathrm{~nm}-\lambda_{\text {em }} 338 \mathrm{~nm}\right)$. The HQ detection limit was $20 \mu \mathrm{g} / \mathrm{l}$.

\subsubsection{Creatinine concentrations in urine}

Creatinine was measured using the Unimate Kit (Roche, France). Absorbance was measured in a Cobas spectrophotometer (Roche, France). The results were used to correct MA and HQ concentrations for urine dilution and expressed as micrograms of MA or HQ per gram of creatinine .

\subsection{Computation of children personal exposure}

As it was impractical to equip the children with passive samplers, we estimated the personal exposure of the children by computing the time-weighted average of the bedroom, day care center and outdoors benzene concentrations for each child. We assumed the average time spent at home, in the day care center, and outdoors to be 15,8 , and 1 hour respectively.. 
Calculations were therefore carried out as follows:

Personal exposure $=($ measured bedroom concentration $\mathrm{x} 15 / 24)+($ mean concentration inside the day care center $\mathrm{x} 8 / 24)+($ mean concentration outside of the day care center $\mathrm{x} 1 / 24)$.

\subsection{Computation of subjects benzene inhalation uptake}

We estimated personal benzene inhalation uptake for each subject as the product of average daily inhalation rate by personal benzene exposure. We assumed the daily inhalation rate for a male child $(0.5-<3$ years; mean body weight $=14 \mathrm{~kg})$, a female child $(0.5-<3$ years; mean body weight $=11 \mathrm{~kg})$, a male adult $(30-<60$ years; mean body weight $=80 \mathrm{~kg})$ and a female adult $(30-<60$ years; mean body weight $=68 \mathrm{~kg})$ to be $0.52,0.51$, and $0.2,0.16 \mathrm{~m}^{3} / \mathrm{kg}$-day, respectively (US-EPA, 1997).

\subsection{Statistical analysis}

Descriptive statistics, mean differences, and regression lines were calculated using Statistica 5.5 software (Statsoft, Inc., 1997). All statistical tests and correlation analyses corrected the highly skewed distributions of the measured concentrations by natural logarithmic transformation. Values below the limit of detection (LD) were set at half its level for data analysis.

Mean differences between groups (Children vs. Parents) were evaluated using paired $t$-test. 


\section{Results}

Objective A. Comparison of the personal benzene exposure and inhalation uptake

The box-plot in Figure 1 summarizes the distribution (min., lower quartile, median, upper quartile and maximum) of benzene concentrations in parents and children bedrooms, as well as of their personal exposures. There were no significant differences between the parent's and children's bedrooms concentrations $(9.1 \pm 6.2$ vs. $10.9 \pm 7.2 ; p=0.16)$ whereas the personal exposure of the parents were higher than their bedroom concentrations (14.4 \pm 7.7 vs. $9.1 \pm$ $6.2 ; p<0.002)$. The mean calculated personal exposure of the children was $(11.09 \pm 6.15$ $\left.\mu \mathrm{g} / \mathrm{m}^{3}\right)$ significantly lower than the parent's personal exposure $(p=0.04)$. Table 2 shows the mean indoor and outdoor concentrations of the day care centers. Despite a higher exposure of the parents, the mean of the estimated benzene inhalation uptake for children was higher than for parents: $5.68 \pm 3.17 \mu \mathrm{g} / \mathrm{kg}$-day vs. $2.51 \pm 1.23 \mu \mathrm{g} / \mathrm{kg}$-day $(p<0.0001)$.

\section{Objective B. Comparison of urinary MA and HQ levels}

The urinary MA and HQ concentrations, with and without creatinine adjustment, are shown in Table 3. The total number of urinary samples obtained from adults and children are, respectively, 200 on 220 foreseen (91\%) and of 183 on 210 foreseen (87\%). Quantifiable levels of MA were found in 315 of 380 samples ( $83 \%$ ). Quantifiable levels of HQ were found in all samples. A slight correlation was found between MA and HQ concentrations $(r=0.13$, $p=0.012, \mathrm{n}=380)$. Concentrations of urinary MA analyzed during 5 days of sampling ranged for children and parents from 0.01 to $13.47 \mathrm{mg} / \mathrm{g}$ creatinine and from 0.004 to 9.04 mg/g creatinine, respectively. Concentrations of urinary HQ ranged for children and parents from 0.14 to $24.75 \mathrm{mg} / \mathrm{g}$ creatinine and from 0.01 to $21.72 \mathrm{mg} / \mathrm{g}$ creatinine respectively. Intraindividual variation of urinary MA concentrations expressed as a coefficient of variation (CV) ranged from 63 to $137 \%$ for children and from 69 to $232 \%$ for parents. Intra-individual 
variation of urinary HQ concentrations ranged, in children and adults, from 13 to $144 \%$ and from 40 to $107 \%$, respectively. The differences in urinary MA and HQ levels between children and parents were examined. The geometric mean values of MA (mg/l), HQ (mg/l) and creatinine $(\mathrm{g} / \mathrm{l})$ in the group of parents were 1.7-, 1.5-, and 2.6-fold higher than the mean concentration of these compounds in the group of children. On the other hand, the mean values of MA and HQ normalized against creatinine ( $\mathrm{mg} / \mathrm{g}$ creatinine) were 1.6- and 1.8-fold higher in the group of children than in the group of parents. The differences in the mean concentrations of MA and HQ (mg/g creatinine) between children and parents were significant in all cases (Table 3). ANOVA analyses (un-paired) of the simultaneous impact of three factors: age, sex and time of examination, on MA concentrations in urine indicated no significant effect of these variables. HQ levels were only significantly influenced by age ( $p=$ 0.024) (Figure 2). The points in Figure 2 correspond to arithmetic means of log transformed values of $\mathrm{HQ}$.

\section{Objective C. Correlation between exposure and urinary metabolite levels}

No statistically significant correlations were found between benzene exposure means and urinary metabolites levels. In the group of parents, benzene personal exposure was most correlated with Friday evening urinary MA and HQ concentrations, $r=0.54(\mathrm{n}=16)$ and $r=$ $0.65(\mathrm{n}=16)$, respectively. The lowest correlation was obtained for Monday evening, $r=0.05$ ( $\mathrm{n}=16)$ and $r=0.09(\mathrm{n}=16)$, respectively. In the group of children, calculated benzene personal exposure was most correlated with the average urinary MA concentration, $r=0.51$ $(\mathrm{n}=21)$. Other $r$ values with daily samples were between 0.03 and 0.38 . Lower correlations were found between calculated benzene personal exposure and urinary HQ concentrations. For the group of parents and children, uptake was similarly uncorrelated to MA and HQ levels (exposure and uptake are linearly related by the inhalation rate factor). 


\section{Discussion}

Our atmospheric measurements show that the personal exposure of adults is generally higher $\left(14.4 \pm 7.7 \mu \mathrm{g} / \mathrm{m}^{3}\right)$ than indoor and outdoor benzene levels $\left(9.1 \pm 6.2 \mu \mathrm{g} / \mathrm{m}^{3} ; 3.5 \pm 0.3 \mu \mathrm{g} / \mathrm{m}^{3}\right)$. Since it was not possible to equip young children with personal samplers, we estimated their personal exposure on the basis of time-weighted average concentrations. This estimated exposure $\left(11.09 \pm 6.15 \mu \mathrm{g} / \mathrm{m}^{3}\right)$ is significantly lower than the measured exposure of the parents. Children's exposure may be underestimated because microenvironments like inside cars, smoky places, etc, have relatively high benzene concentrations and could not be taken into account (Gonzalez-Flesca et al., 2000). However, the children of our study are very young and their activity patterns are less varied than their parent's. Raaschou-Nielsen et al. (1997) observed in 98 children aged between 4 and 12 years, equipped with personal monitors, a median personal exposure to the benzene of $5.4 \mu \mathrm{g} / \mathrm{m}^{3}$ for 56 children living in an urban area and $4.5 \mu \mathrm{g} / \mathrm{m}^{3}$ for 40 children living in a rural area. Indoor measurements show unusually high indoor concentrations of benzene in day care center B, section 1 (Table 2). In that area the level was $35.5 \mu \mathrm{g} / \mathrm{m}^{3}$ versus a next highest level of only $11.1 \mu \mathrm{g} / \mathrm{m}^{3}$ in center $\mathrm{B}$, section 2. This is probably due to repair and maintenance work (painting, new floor materials...) that took place within 2 months before our measurements. At the request of the day care center B, control measurements made one-year later showed benzene levels close to those of day care centers $\mathrm{A}$ and $\mathrm{C}$.

Comparison with studies in children and adults not occupationally exposed shows that our MA results are generally higher than the means reported for adults (Dor et al., 1999; Scherer et al., 1998) and children (Amodio-Cocchieri et al., 2001; Weaver et al., 1996). Several reasons for these high values are possible. Misidentification of MA and HQ is unlikely since both retention time and UV absorbance by diode array detection were used for HPLC 
confirmation. However, ingestion of foods containing sorbic acid-based preservatives has the potential to increase MA excretion so significantly that MA may not be a sensitive biomarker for environmental benzene exposures. Weaver et al. (2000) found that ingestion of refrigerated flavored drinks and sweet snack foods resulted in the excretion of large amounts of MA in adults and children. An average MA peak of $0.45 \mathrm{mg} / \mathrm{g}$ creatinine was found in five adults after ingestion of a flavored drink and a mean of $0.67 \mathrm{mg} / \mathrm{g}$ creatinine was found in 6 adults after ingestion of a cupcake. Several other studies have addressed the potential effect of sorbic acid on MA specificity (Ducos et al., 1990; Pezzagno et al., 1997; Pezzagno et al., 1999; Renner et al., 1999; Ruppert et al., 1997). Ingestion of different amounts of sorbic acid (200-600 mg) can result in an increase of MA levels (in spot or 24h urine samples) from a baseline below the limit of detection to 90-fold greater MA level. Ingestion of preserved food varies from one country to another. Therefore, it is likely that sorbic acid ingestion is a factor in the variable correlation between MA and benzene exposure measurements reported in the literature. Some authors have found significant correlations between benzene in air and MA levels in 24 non-smoking bicyclists (Bergamaschi et al., 1999). Others, however, have not found significant correlations, at occupational exposure levels lower than $0.25 \mathrm{ppm}$ (Gobba et al., 1997; Ong et al., 1996). In addition, several authors have reported the occasional observation of unexpectedly high MA levels in non-occupationally exposed control subjects (Gobba et al., 1997; Isabell et al., 1999; Johnson et al., 1992; Qu et al., 2000; Weaver et al., 1996). The French mean daily intake of sorbic acid and its salts was estimated at $2.63 \mathrm{mg} / \mathrm{kg}$ day which corresponds to $184 \mathrm{mg} /$ day ingestion for a $70 \mathrm{~kg}$ adult (Verger et al., 1998).

In our study, benzene personal exposures were not significantly correlated with urinary MA concentrations. This suggests that in the absence of a measure or control of sorbic acid intake, urinary MA is not a reliable biomarker for benzene exposure (Sanguinetti et al., 2001). 
Our HQ mean concentrations were also higher than the mean concentrations observed in occupationally exposed adults (Lee et al., 1993b; Ong, C. N. et al., 1994; Ong, C.N. et al., 1994; Rothman et al., 1998). Relatively few studies have been conducted to examine the relation between urinary HQ and benzene exposure since the common ingestion of dietary phenol contributes to the urinary excretion of HQ (DeCaprio, 1999). However, a better correlation between HQ and benzene exposure $(<0.25 \mathrm{ppm})$ than between MA and benzene exposure was observed in occupationally exposed subjects $(r=0.44, p<0.01$ and $r=0.14, p$ $<0.05$, respectively) (Ong et al., 1996). The inter-individual variability of our HQ concentrations was lower than those of MA (from 13 to $144 \%$ vs. 63 to $232 \%$, respectively). HQ levels were also significantly influenced by the age (Figure 2). In the absence of control or precise estimation of confounding factors (sorbic acid ingestion, intake of food-borne phenolic compounds...), MA and HQ do not appear to be specific marker of low benzene exposures.

Despite these concerns about the sensitivity of MA and HQ as environmental benzene biomarkers, our results show that the creatinine adjusted levels of MA and HQ were higher in the urine of children than in that of parents (Table 3). It is common practice to adjust the analytical values determined in spot samples of urine with creatinine concentration in order to correct for varying dilution of urine (Araki et al., 1986; Greenberg et al., 1989; Ong et al., 1996). Dilution of urine fluctuates considerably in a given subject during the day, especially after ingestion of liquids or sweating. Weaver et al. (1996) observed that the creatinine urine levels were significantly lower in nondetectable MA urine samples. Creatinine adjustment therefore removes potentially significant source of bias and variation in urine concentration of MA and HQ. However, a strong correlation exists between creatinine elimination rate and body mass (Boeniger et al., 1993). Because of this, benzene metabolite concentrations in urine 
are higher in adults than in children when unadjusted for creatinine, while the inverse is found with creatinine-adjusted concentration. This apparent paradox is explained away when one realizes that concentration values expressed as $\mathrm{mg} / \mathrm{g}$ of creatinine approximate values expressed as $\mathrm{mg} / \mathrm{kg}$ of body mass which is a better measure of internal exposure. Therefore, adults in our study, because of their high total benzene uptake, excrete more benzene metabolites per unit time. However, internal exposure of the children to benzene or its metabolites, when assessed by unit of body mass, is higher than that of their parents. Children might metabolize a higher proportion of benzene to MA and HQ than adults. It is also possible as discussed by Gobba et al. (1997) that there may exist in the general population "poor MA metabolizers" and "efficient MA metabolizers". In addition, children in our study have a higher benzene uptake per unit of body mass than adults. Benzene inhalation uptake per kg was twice higher in our group of children than in our group of parents.

The mechanism(s) of leukemia induction by benzene are not yet fully understood. Unlike benzene exposure, administration of phenol, a major metabolite of benzene, to rats does not induce hematotoxicity (US-EPA 1998), whereas Witz et al. (1996) have demonstrated that trans, trans-muconaldehyde, a precursor of $\mathrm{MA}$, is myelotoxic in mice. It has been hypothesized that combinations of hydroquinone and phenol, or muconaldehyde and hydroquinone, may be involved leukemogenesis (Eastmond et al., 1987). This could apply to benzene induced leukemia but could also be the basis for a link between leukemia and dietary factors (McDonald et al., 2001). We found that children excrete relatively higher levels of MA and HQ (when expressed in $\mathrm{mg} / \mathrm{g}$ creatinine) than adults. Therefore, they may be at relatively higher risk of developing leukemia, independently of benzene exposure. 


\section{ACKNOWLEDGMENTS}

We would like to thank the children and parents who participated in this study. We are also grateful to the staff of the day care centers and the town council of Rouen for their support and assistance in this project. We wish to express our thanks to Mrs N. François, Mrs A. Frézier, Mrs C. Gillet, Mr D. Granier and Mr J-C Pinard for their analytical and technical assistance.

This study was supported in part by the French PREDIT-PRIMEQUAL (Inter-ministerial land transport research and innovation program) (grant $\mathrm{n}^{\circ}$ P20580) and the French Agency for Environment and Energy Management (ADEME) (grant $\mathrm{n}^{\circ}$ BOU9930) 


\section{REFERENCES}

Amodio-Cocchieri R, Del Prete U, Cirillo T, Agozzino E, Scarano G. Evaluation of benzene exposure in children living in Campania (Italy) by urinary trans,trans-muconic acid assay. J Toxicol Environ Health A 2001; 63(2): 79-87.

Araki S, Aono H, Yokoyama K, Murata K. Filterable plasma concentration, glomerular filtration, tubular balance, and renal clearance of heavy metals and organic substances in metal workers. Arch Environ Health 1986; 41(4): 216-221.

Bates M, Gonzalez-Fleska N, Cocheo V, Sokhi R. Ambient VOC monitoring by diffusive sampling. Compatibility of high uptake rate samplers with thermal desorption. Analyst 1997; 122: 1481-1484.

Bergamaschi E, Brustolin A, De Palma G, Manini P, Mozzoni P, Andreoli R, Cavazzini S, Mutti A. Biomarkers of dose and susceptibitity in cyclists exposed to monoaromatic hydrocarbons. Toxicol Lett 1999; 108: 241-247.

Boeniger MF, Lowry LK, Rosenberg J. Interpretation of urine results used to assess chemical exposure with emphasis on creatinine adjustements: a review. Am Ind Hyg Ass J 1993; 54(10): 615-627.

DeCaprio A. The toxicology of Hydroquinone - Relevance to occupational and environmental exposure. Crit Rev Toxicol 1999; 29(3): 283-330.

Dor F, Dab W, Empereur-Bissonnet P, Zmirou D. Validity of biomarkers in enviromental health studies : The case of PAHs and benzene. Crit Rev Toxicol 1999; 28(2): 69-80.

Ducos P, Gaudin R, Robert A, Francin JM, Maire C. Improvement in HPLC analysis of urinary trans,trans-muconic acid, a promising substitute for phenol in the assessment of benzene exposure. Int Arch Occup Environ Health 1990; 62(7): 529-534. 
Eastmond DA, Smith MT Irons RD. An interaction of benzene metabolites reproduces the myelotoxicity observed with benzene exposure. Toxico. Appl. Pharmacol. 1987; 91:85-95.

Gobba F, Rovesti S, Borella P, Vivoli R, Caselgrandi E, Vivoli G. Inter-individual variability of benzene metabolism to trans,trans-muconic acid and its implications in the biological monitoring of occupational exposure. Sci Total Environ 1997; 199(1-2): 4148.

Gonzalez-Flesca N, Bates M, Delmas V, Cocheo V. Benzene exposure assessment at indoor, outdoor and personal levels. The French contribution to the LIFE MACBETH programme. Environ Monit Assess 2000; 65: 59-67.

Greenberg GN, Levine RJ. Urinary creatinine excretion is not stable: a new method for assessing urinary toxic substance concentrations. J Occup Med 1989; 31(10): 832-838.

Isabell M, Ricker J, Gordian ME, Duffy LK. Use of biomarkers in an indoor air study: Lack of correlation between aromatic VOCs with respective urinary biomarkers. Sci Total Environ 1999; 241: 151-159.

Johnson ES, Lucier G. Perspectives on risk assessment impact of recent reports on benzene. Am J Ind Med 1992; 21(5): 749-757.

Lee BL, New AL, Kok PW, Ong HY, Shi CY, Ong CN. Urinary trans,trans-muconic acid determined by liquid chromatography: application in biological monitoring of benzene exposure. Clin Chem 1993a; 39(9): 1788-1792.

Lee BL, Ong HY, Shi CY, Ong CN. Simultaneous determination of hydroquinone, catechol and phenol in urine using high-performance liquid chromatography with fluorimetric detection. J Chromatogr 1993b; 619(2): 259-266. 
McDonald TA, Holland NT, Skibola C, Duramad P Smith MT. Hypothesis: phenol and hydroquinone derived mainly from diet and gastrointestinal flora activity are causal factors in leukemia. Leukemia 2001; 15(1):10-20.

Ong CN, Kok PW, Ong HY, Shi CY, Lee BL, Phoon WH, Tan KT. Biomarkers of exposure to low concentrations of benzene: a field assessment. Occup Environ Med 1996; 53(5): 328-333.

Ong CN, Lee BL. Determination of benzene and its metabolites: application in biological monitoring of environmental and occupational exposure to benzene. J Chromatogr B Biomed Appl 1994; 660(1): 1-22.

Ong CN, Lee BL, Shi CY, Ong HY, Lee HP. Elevated levels of benzene-related compounds in the urine of cigarette smokers. Int J Cancer 1994; 59: 177-180.

Pezzagno G, Maestri L. The specificity of trans,trans-muconic acid as a biological indicator of low levels of environmental benzene. Indoor Built Environ. 1997; 6: 12-18.

Pezzagno G, Maestri L, Fiorentino ML. Trans,trans-muconic acid, a biological indicator to low levels of environmental benzene: some aspects of its specificity. Am J Ind Med 1999; 35(5): 511-518.

Qu Q, Melikian AA, Li G, Shore R, Chen L, Cohen B, Yin S, Kagan MR, Li H, Meng M, Jin X, Winnik W, Li Y, Mu R, Li K. Validation of biomarkers in humans exposed to benzene: urine metabolites. Am J Ind Med 2000; 37(5): 522-531.

Raaschou-Nielsen O, Lohse C, Thomsen BL, Skov H, Olsen JH. Ambiant air levels and the exposure of children to Benzene, Toluene, and Xylenes in Denmark. Environ. Res. 1997; 75: 149-159.

Renner T, Baer-Koetzle M, Scherer G. Determination of sorbic acid in urine by gas chromatography-mass spectrometry. J Chromatogr A 1999; 847(1-2): 127-133. 
Rothman N, Bechtold WE, Yin SN, Dosemeci M, Li GL, Wang YZ, Griffith WC, Smith MT, Hayes RB. Urinary excretion of phenol, catechol, hydroquinone, and muconic acid by workers occupationally exposed to benzene. Occup Environ Med 1998; 55(10): 705711.

Ruppert T, Scherer G, Tricker AR, Adlkofer F. Trans,trans-muconic acid as a biomarker of non-occupational environmental exposure to benzene. Int Arch Occup Environ Health 1997; 69(4): 247-251.

Sanguinetti G, Accorsi A, Barbieri A, Raffi GB, Violante FS. Failure of urinary trans,transmuconic acid as a biomarker for indoor environmental benzene exposure at ppb levels. J Toxicol Environ Health A 2001; 63: 599-604.

Scherer G, Renner T, Meger M. Analysis and evaluation of trans,trans-muconic acid as a biomarker for benzene exposure. J Chromatogr B Biomed Sci Appl 1998; 717(1-2): 179-199.

US-EPA Exposure Factors Handbook. 1997. EPA/600/P-95/002Fa

US-EPA Carcinogenic Effects of Benzene: An Update. 1998. EPA/600/P-97/001F

Verger P, Chambolle M, Babayou P, Le Breton S, Volatier J. Estimation of the distribution of the maximum theoretical intake for ten additives in France. Food Add Contam 1998; 15(7): 759-766.

Wallace LA. The exposure of the general population to benzene. Cell Biol Toxicol. 1989; 5(3): 297-314.

Weaver VM, Buckley T, Groopman JD. Lack of specificity of trans,trans-muconic acid as a benzene biomarker after ingestion of sorbic acid-preserved foods. Cancer Epidemiol Biomarkers Prev 2000; 9(7): 749-755.

Weaver VM, Davoli CT, Heller PJ, Fitzwilliam A, Peters HL, Sunyer J, Murphy SE, Goldstein GW, Groopman JD. Benzene exposure, assessed by urinary trans,trans- 
muconic acid, in urban children with elevated blood lead levels. Environ Health Perspect 1996; 104(3): 318-323.

Witz G, Kirley TA, Maniara WM, Mylavarapu VJ Goldstein BD. The metabolism of benzene to muconic acid, a potential biological marker of benzene exposure. Adv Exp Med Biol 1991; 283:613-618. 
Table 1 : Characteristics of the study population.

\begin{tabular}{|c|c|c|c|c|c|}
\hline $\begin{array}{c}\text { Day care } \\
\text { center }\end{array}$ & Location & Date of sampling & $\begin{array}{l}\text { Number of } \\
\text { families }\end{array}$ & $\begin{array}{c}\text { Number of } \\
\text { children }\end{array}$ & Number of parents* \\
\hline $\mathrm{A}$ & Town center & $25-29 /$ oct/99 & 9 & 10 & 10 \\
\hline B section 1 & Town center & 29/nov - 3/dec/99 & 2 & 2 & 2 \\
\hline B section 2 & Town center & 29/nov - 3/dec/99 & 2 & 2 & 2 \\
\hline B section 3 & Town center & $29 /$ nov - 3/dec/99 & 2 & 2 & 2 \\
\hline $\mathrm{C}$ & Out of town & $22-26 / d e c / 99$ & 5 & 5 & 6 \\
\hline Total & & & 20 & 21 & 22 \\
\hline
\end{tabular}

* Father, mother or both. 
Table 2. Mean benzene concentrations in the three day care centers $\left(\mu \mathrm{g} / \mathrm{m}^{3}\right)$.

\begin{tabular}{|c|c|c|c|c|}
\hline \multirow[t]{2}{*}{ Day care center } & \multicolumn{2}{|r|}{ Indoor } & \multicolumn{2}{|c|}{ Outdoor } \\
\hline & $\mathrm{n}$ & Mean \pm SD & $\mathrm{n}$ & Mean \pm SD \\
\hline A & 8 & $10.5 \pm 1.9$ & 6 & $5.0 \pm 2.1$ \\
\hline B section 1 & 4 & $35.5 \pm 13.5$ & 2 & $7.6 \pm 0.3$ \\
\hline B section 2 & 4 & $11.1 \pm 6.9$ & 2 & $7.6 \pm 0.3$ \\
\hline B section 3 & 4 & $9.1 \pm 5.0$ & 2 & $7.6 \pm 0.3$ \\
\hline $\mathrm{C}$ & 5 & $7.9 \pm 3.4$ & 6 & $3.5 \pm 0.3$ \\
\hline
\end{tabular}


Table 3. Summary statistics for the urinary levels of MA, HQ and creatinine in a group of parents and their children.

\begin{tabular}{|c|c|c|c|c|c|c|c|c|c|c|c|}
\hline Variable & \multicolumn{5}{|c|}{ Parents $(\mathrm{n}=22)$} & \multicolumn{5}{|c|}{ Children $(\mathrm{n}=21)$} & $p^{\mathrm{c}}$ \\
\hline MA (mg/g creatinine) & $0.73(1.24)$ & $0.21(6.29)$ & 0.004 & 9.04 & 199 & $0.85(1.40)$ & $0.31(4.85)$ & 0.01 & 13.47 & 181 & 0.008 \\
\hline HQ (mg/l) & $2.50(2.42)$ & $1.20(2.77)$ & 0.01 & 27.67 & 200 & $1.11(0.99)$ & $0.78(2.44)$ & 0.05 & 6.63 & 179 & $<0.0001$ \\
\hline Creatinine $(\mathrm{g} / \mathrm{l})$ & $1.24(0.59)$ & $1.09(1.75)$ & 0.20 & 2.74 & 200 & $0.49(0.30)$ & $0.41(1.85)$ & 0.05 & 2.31 & 183 & $<0.0001$ \\
\hline
\end{tabular}

${ }^{\mathrm{a}}$ arithmetic mean and arithmetic standard deviation.

${ }^{\mathrm{b}}$ geometric mean and geometric standard deviation.

${ }^{\mathrm{c}} 2$-tail significance of differences between geometric means by paired Student's $t$-test on log-transformed data for 21 parents and their 21 children (for the male child with with 2 participating parents, only the father was kept for pairing).

${ }^{\mathrm{d}}$ number of observations.

${ }^{\mathrm{e}}$ Not Detected. 


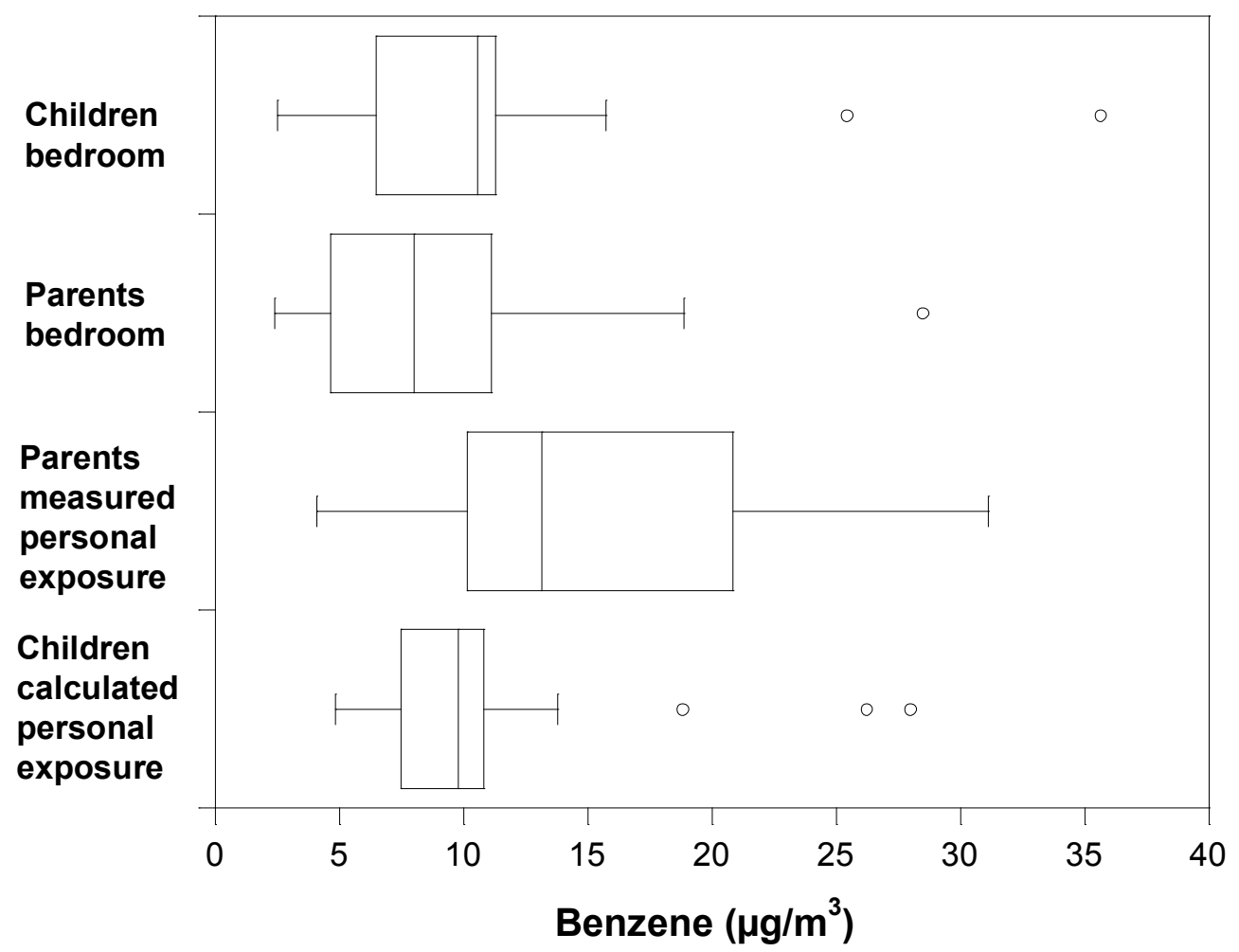

Figure 1. Box-plot showing the distribution of the parent's and children personal exposure as well as the bedroom's indoor concentrations $\left(\mu \mathrm{g} / \mathrm{m}^{3}\right)$. 


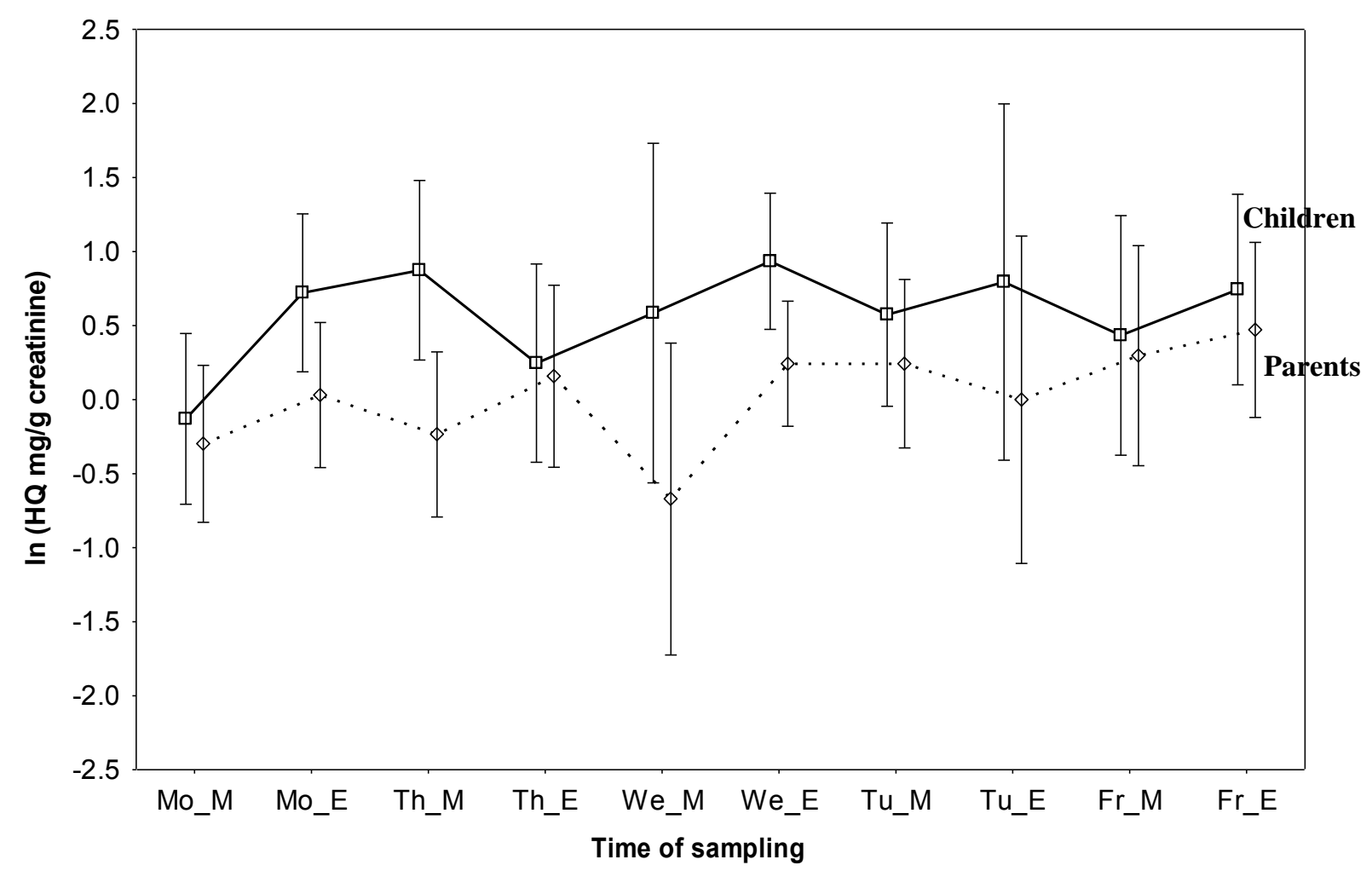

Figure 2. Concentration of urinary HQ of children and parents on the time of sampling with regard to their age. 